\title{
Characterization of the growth of Lactobacillus plantarum in milk in dependence on temperature
}

\author{
Zuzana Matejčeková, Denisa Liptáková, \\ Sabína Spodniaková, Lubomír Valík \\ Department of Nutrition and Food Quality Assessment, Faculty of Chemical and Food Technology, \\ Slovak University of Technology in Bratislava, Radlinského 9, SK 812 37, Bratislava \\ zuzana.matejcekova@stuba.sk
}

\begin{abstract}
The effect of temperature on the growth dynamics of Lactobacillus plantarum in the model environment of UHT milk was investigated. Based on the experiments between temperatures ranged from 8 to $40{ }^{\circ} \mathrm{C}$, growth dynamics of the studied isolate was positively determined by the cultivation temperature that led to increasing intensity of growth in the exponential phase (except for temperatures 38 and $40{ }^{\circ} \mathrm{C}$ ). Final counts in stationary phase have reached concentrations about $10^{7} \mathrm{CFU} \cdot \mathrm{ml}^{-1}$ from initial $10^{3} \mathrm{CFU} \cdot \mathrm{ml}{ }^{-1}$, except for marginal 8 and $40^{\circ} \mathrm{C}$. Experimentally, it was found, that optimal temperature was close to $37^{\circ} \mathrm{C}$, where the fastest specific growth rate in an exponential phase was recorded $\left(\mu=0.7683 \mathrm{~h}^{-1}, \mathrm{t}_{\mathrm{d}}=54 \mathrm{~min}\right)$ and the stationary phase was reached after $24 \mathrm{~h}$ of incubation. During the growth and multiplication of $L b$. plantarum, no significant decrease of $\mathrm{pH}$ values in comparison to initial ones in dependence on temperature were determined (0.00-0.24 units).
\end{abstract}

Keywords: lactic acid bacteria, Lactobacillus plantarum, predictive microbiology

\section{Introduction}

Genus Lactobacillus is by far the largest of the genera included in a group of lactic acid bacteria (LAB) (Tannock, 2004) and is recognized as being phylogenetically very heterogeneous (broad interval of \% G-C content). Lactobacilli are characterized as gram-positive, microaerophilic, non-sporeforming, non-flagellated rods or coccobacilli found in diverse environments, including nutrient-rich dairy products, microbial-heavy host habitats (human mucosal surfaces), as well as natural ecological niches (Barrangou et al., 2011). In humans and animals, lactobacilli are considered as essential components, playing a large variety of health promoting functions, such as immunomodulation, intestinal integrity and pathogen resistance (Vaughan et al., 2005). For those reasons some strains have traditionally been used as probiotics in various food commodities (Smetánková et al., 2012). In many cases, lactobacilli occupy a central role in fermentation processes as a starter cultures with a long and safe history since they contribute to the conservation, flavour and texture of the final products. While the fermentative conversion of carbohydrates present in the raw materials mainly into lactic acid is the main function, production of anti-microbial peptides, exopolysaccharides and a variety of other metabolites are other important properties of this genus (Vries et al., 2006). Within the genus Lactobacillus, Lactobacillus plantarum is a member of facultatively heterofermentative group of lactobacilli. According to Embden-MeyerhofParnas pathway it is able to convert hexoses into lactic acid (Arasu et al., 2015). Lb. plantarum has also the coding capacity for uptake and utilization of many different sugars, uptake of peptides, and formation of most amino acids. The large number of surfaceanchored proteins suggests that $L b$. plantarum has the potential to associate with many different surfaces and potential substrates for growth. In addition, the relatively high number of genes encoding regulatory functions indicated the ability to adapt to many different conditions. Taken all together, this reflects the potential of $\mathrm{Lb}$. plantarum to grow in a large range of environmental niches (Kleerebezem et al., 2003). It is commonly found in the human gastrointestinal tract and can be involved in a variety of dairy, meat, and vegetable fermentations. Furthermore, $L b$. plantarum can be involved in spoilage of foods, such as meat or wine (Vries et al., 2006). Although the technologically important parameters like optimal $\mathrm{pH}$ and temperature for industrially used strains are well known, the alterations in the quantitative growth characteristics like specific growth rate $(\mu)$ with changing environmental factors are relatively poorly studied.

As temperature represents an important factor in the microorganism growth, in control of bioprocesses in biotechnology and safe handling of goods, especially in food industry, describing the temperature effect on the microbial growth parameters is required. 


$$
\mu_{\text {max }}=\frac{\mu_{o p t}\left(T-T_{\max }\right)\left(T-T_{\min }\right)^{2}}{\left(T_{o p t}-T_{\text {min }}\right)\left[\left(T_{o p t}-T_{\text {min }}\right)\left(T-T_{o p t}\right)-\left(T_{o p t}-T_{\text {max }}\right)\left(T_{o p t}+T_{\min }-2 T\right)\right]}
$$

That is why this work deals with the quantification of temperature effect on the growth of $L b$. plantarum in real growth media.

\section{Material and methodology}

\section{Microorganism}

Lactobacillus plantarum was isolated from breast milk and identification was provided by the Food Research Institute in Bratislava, Slovakia (Liptáková et al., 2016). The isolate of $\mathrm{Lb}$. plantarum was maintained in de Man Rogosa Sharpe (MRS) broth (Biokar Diagnostics, Beauvais, France) at $6 \pm 0.5^{\circ} \mathrm{C}$.

\section{Substrate inoculation and conditions of cultivation} The standard suspension of the microorganism was prepared by overnight incubation at $37 \pm 0.5^{\circ} \mathrm{C}$ $\left(5 \% \mathrm{CO}_{2}\right)$ in MRS broth and used in the individual experiments for inoculation of pre-tempered ultrapasteurised (UHT) milk with $1.5 \%$ fat content (Rajo, Bratislava, Slovakia) in a concentration of approximately $10^{3} \mathrm{CFU} \cdot \mathrm{ml}^{-1}$. Two parallel static cultivations of UHT milk samples were carried out at temperatures ranging from 8 to $40 \pm 0.5^{\circ} \mathrm{C}$ under aerobic conditions.

\section{Enumeration of bacteria and determination of active acidity}

Serial ten-fold dilutions of samples were prepared in a solution of $0.85 \% \mathrm{NaCl}(\mathrm{w} / \mathrm{v})$ and $0.1 \%(\mathrm{w} / \mathrm{v})$ peptone (Biolife, Milan, Italy) at appropriate time intervals. Presumptive numbers of $L b$. plantarum were estimated using MRS agar (Biokar Diagnostics, Beauvais, France) according to the STN ISO 15214. Inoculated Petri dishes with $L b$. plantarum were cultivated at anaerobic conditions $37 \pm 0.5{ }^{\circ} \mathrm{C}(5 \%$ $\left.\mathrm{CO}_{2}\right)$ for 48 hours. The $\mathrm{pH}$ values were measured at the same time as the microbiological determination using the pH meter WTW 720 (Inolab, Weilheim, Germany).

\section{Evaluation of growth curves and metabolic param- eters}

The growth parameters of studied microorganism in inoculated UHT milks were fitted and calculated using the mechanistic model DMFit by Baranyi and Roberts (1994). Growth and metabolic parameters were calculated from each growth curve, from two parallel experiments. Valík et al., (2008) evaluated that the coefficient of variation $(\mathrm{CV})$ of the growth rates for 15 strains of Staphylococcus aureus was as low as $7.1 \%$, despite the errors connected with cultivation methods of determination microbial counts. When 6 growth curves for a single strain were studied in two independent experiments, a CV of $1.2 \%$ for the growth rate was determined.

Specific growth rates $\mu\left(\mathrm{h}^{-1}\right)$ were recalculated from the $\log _{10}$ based growth rates $\left(G_{R}\right)$ according the equation $\mu=\ln 10 \cdot G_{R}$.

The cardinal temperature model with inflection (CTMI) was used to describe the influence of selected environmental factor on the data. The effect of temperature on the specific growth rate is described by the equation (1), where $T_{\text {min }}\left({ }^{\circ} \mathrm{C}\right)$ is the temperature below which no growth is observed, $T_{\max }\left({ }^{\circ} \mathrm{C}\right)$ is the temperature above which no growth occurs and $T_{o p t}\left({ }^{\circ} \mathrm{C}\right)$ is the temperature at which the maximum specific growth rate equals its optimal value $\left(\mu_{\text {opp }}\right)$ (Rosso et al., 1993).

\section{Results and discussion}

Growth trials with $L b$. plantarum in UHT milk were performed at $8,12,15,18,21,25,30,34,35,37$, 38 and $40 \pm 0.5^{\circ} \mathrm{C}$. A temperature range was selected in order to detect the entire growth ability of the microorganism. Growth curves at all temperatures are shown in Fig. 1; at 8, 12, 15, 18, 21 and 25 at Fig. 1a) and 30, 34, 35, 37, 38 and 40 at Fig. 1b). Calculated growth parameters at 8, 12, 15, 18, 21, $25 \pm 0.5^{\circ} \mathrm{C}$ are summarized in Table 2 and 30,34 , $35,37,38$ and $40 \pm 0.5^{\circ} \mathrm{C}$ in Table 3 .

During the growth and multiplication of $L b$. plantarum no significant changes of $\mathrm{pH}$ values (Tab. 1 ) were recorded in comparison to initial state in dependence on temperature (0.00-0.24 units). This can be explained by the low ability of $\mathrm{Lb}$. plantarum to utilize lactose and convert pyruvate to lactate in a rate to match the glycolysis (Jyoti et al., 2004). Smetanková et al., (2012) reported faster decrease of $\mathrm{pH}$ values in MRS broth under anaerobic than under aerobic conditions in case of $\mathrm{Lb}$. plantarum 115. In comparison, Salmerón et al. (2014) evaluated the growth and metabolism of $L b$. plantarum in cereal beverages (oat, barley and malt substrates), where $\mathrm{pH}$ values decreased below 3.7 after $10 \mathrm{~h}$ of fermentation.

Despite the slight acid production, Lactobacillus plantarum showed good growth in UHT milk with specific growth rates ranging between 0.0049 to $0.7683 \mathrm{~h}^{-1}$. In the stationary phase, $L b$. plantarum reached counts in average $10^{7} \mathrm{CFU} \cdot \mathrm{ml}^{-1}$ at studied temperatures, except for marginal ones (8 and $40{ }^{\circ} \mathrm{C}$ ) from initial $10^{2}-10^{3} \mathrm{CFU} \cdot \mathrm{ml}^{-1}$. 
Tab. 1. The effect of temperature on $\mathrm{pH}$ values in UHT milk.

\begin{tabular}{cccc}
\hline Temperature $\left[{ }^{\circ} \mathbf{C}\right]$ & $\mathbf{p H}_{\mathbf{0}}$ & $\mathbf{p H}_{\text {end }}$ & $\mathbf{k}_{\mathbf{p H}}\left[\mathbf{h}^{-1}\right]$ \\
\hline $\mathbf{8}$ & 6.60 & 6.67 & 0.0001 \\
$\mathbf{1 2}$ & 6.72 & 6.51 & -0.0036 \\
$\mathbf{1 5}$ & 6.70 & 6.54 & -0.0028 \\
$\mathbf{1 8}$ & 6.58 & 6.48 & -0.0022 \\
$\mathbf{2 1}$ & 6.64 & 6.40 & -0.0019 \\
$\mathbf{2 5}$ & 6.59 & 6.52 & -0.0016 \\
$\mathbf{3 0}$ & 6.48 & 6.36 & -0.0068 \\
$\mathbf{3 4}$ & 6.45 & 6.45 & -0.0003 \\
$\mathbf{3 5}$ & 6.50 & 6.33 & -0.0038 \\
$\mathbf{3 7}$ & 6.53 & 6.40 & -0.0161 \\
$\mathbf{3 8}$ & 6.48 & 6.37 & -0.0034 \\
$\mathbf{4 0}$ & 6.58 & 6.35 & -0.0022 \\
\hline
\end{tabular}

$\mathrm{pH}_{0}-$ initial $\mathrm{pH}$ value, $\mathrm{pH}_{\text {end }}-$ final $\mathrm{pH}$ value, $\mathrm{k}_{\mathrm{pH}}-$ rate constant for the decrease of $\mathrm{pH}$.

Similar results reported Pelikánová et al., (2011) in Lactobacillus paracasei subsp. paracasei 1753 in UHT milk. At the lowest temperature $\left(8^{\circ} \mathrm{C}\right), L b$. plantarum grew, although slowly $\left(\mu=0.0049 \mathrm{~h}^{-1}\right.$; $\mathrm{t}_{\mathrm{d}}=141.5 \mathrm{~h}$ ) without previous lag-phase. In this case, the experiment lasted for 23 days. Valík et al., (2008) in their study reported about $93 \%$ higher specific growth rate in $L b$. rhamnosus GG in UHT milk $\left(0.069 \mathrm{~h}^{-1}\right)$ that reached stationary phase after 9 days of incubation. Increase of incubation temperature $\left(12{ }^{\circ} \mathrm{C}\right)$ resulted into increase of specific growth rate $\left(0.0242 \mathrm{~h}^{-1}\right)$ and the stationary phase was reached on the $20^{\text {th }}$ day of aerobic cultivation. At the temperature of $15{ }^{\circ} \mathrm{C}$, the specific growth rate increased about $63 \%$ in comparison to $12{ }^{\circ} \mathrm{C}$ and about $93 \%$ than at $8{ }^{\circ} \mathrm{C}$. At $15{ }^{\circ} \mathrm{C}$, specific growth rate of $L b$. plantarum was characterized as the same as the specific growth rate of Lactobacillus rhamnosus VT1 evaluated in study Liptáková et al., (2007).

At $18{ }^{\circ} \mathrm{C}$, the stationary phase was reached after 6 days of incubation $\left(\mu=0.1082 \mathrm{~h}^{-1}\right)$, and the maximal density of $\mathrm{Lb}$. plantarum was $7.8 \mathrm{log}$ counts. Aerobic cultivation of $\mathrm{Lb}$. plantarum at $21^{\circ} \mathrm{C}$ decreased lag phase duration almost 10 times in comparison with that at $12^{\circ} \mathrm{C}$. Pelikánová et al., (2011) observed specific growth rate of Lactobacillus paracasei subsp. paracasei in UHT milk $0.216 \mathrm{~h}^{-1}$ at $21{ }^{\circ} \mathrm{C}$ that represents $14 \%$ difference in comparison with our results.

Similar trends were observed at temperatures ranging from $30^{\circ} \mathrm{C}$ to $37^{\circ} \mathrm{C}$ with an acceleration of the specific growth rate upon increasing the incubation temperature and the lag phase duration was shortened (Table 3). The time at which $L b$. plantarum reached stationary phase also decreased. At $37^{\circ} \mathrm{C}$, the shortest time necessary to reach the stationary phase (24 h) was achieved and the maximal specific growth rate was observed $\left(0.7683 \mathrm{~h}^{-1}\right)$. With further increasing the incubation temperature, this time was prolonged. The given experimental temperature was expected to be optimal for the growth and multiplication of $\mathrm{Lb}$. plantarum.

Within the last selected temperature $\left(40{ }^{\circ} \mathrm{C}\right)$ the specific growth rate decreased by about $62 \%$ in comparison to $37^{\circ} \mathrm{C}$, during which $L b$. plantarum reached the stationary phase after 4 days of incubation $\left(\mathrm{N}_{\max }=6.78 \log \mathrm{CFU} \cdot \mathrm{ml}^{-1}\right)$. Valík et al., (2008) reported about $88 \%$ higher specific growth rate in case of $L b$. rhamnosus $\mathrm{GG}$ at $41^{\circ} \mathrm{C}\left(1.978 \mathrm{~h}^{-1}\right)$.

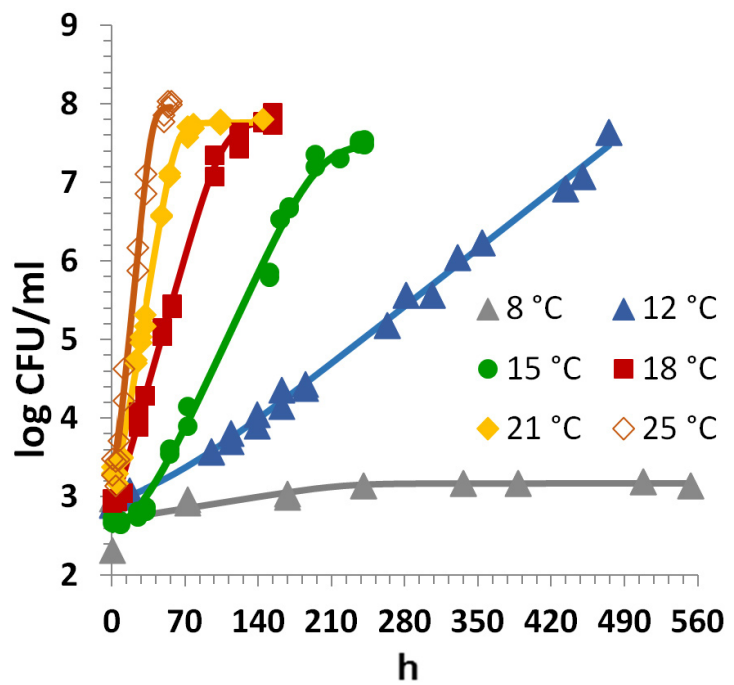

a)

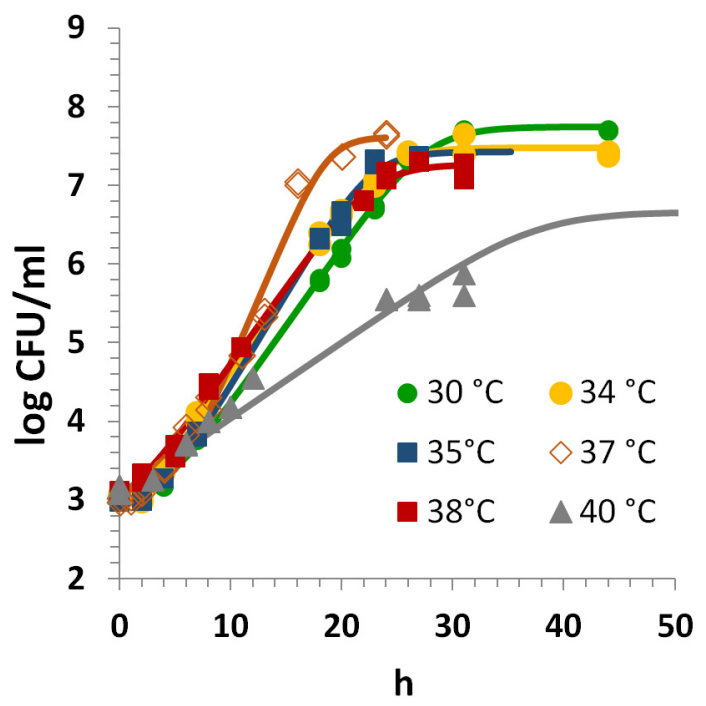

b)

Fig. 1. Growth dynamics of $L b$. plantarum with respect to incubation temperature. 
Tab. 2. Growth characteristics of $L b$. plantarum at $8,12,15,18,21,25 \pm 0.5^{\circ} \mathrm{C}$.

\begin{tabular}{|c|c|c|c|c|c|}
\hline $\begin{array}{l}\text { Temperature } \\
{\left[{ }^{\circ} \mathrm{C}\right]}\end{array}$ & $\begin{array}{c}\mu \\
{\left[h^{-1}\right]}\end{array}$ & $\begin{array}{c}\mathbf{N}_{0} \\
{\left[\log \mathrm{CFU} \cdot \mathrm{ml}^{-1}\right]}\end{array}$ & $\begin{array}{c}\mathbf{N}_{\max } \\
{\left[\log \text { CFU } \cdot \mathbf{m l}^{-1}\right]}\end{array}$ & $\begin{array}{c}\lambda \\
{[\mathbf{h}]}\end{array}$ & $\begin{array}{c}\mathbf{t}_{\mathbf{d}} \\
{[\mathbf{h}]}\end{array}$ \\
\hline 8 & $0.0010^{*}$ & 2.97 & 3.14 & - & 693.1 \\
\hline 8 & $0.0212^{*}$ & 2.32 & 3.14 & - & 32.7 \\
\hline 8 & $0.0049^{\circ}$ & 2.65 & 3.14 & - & 141.5 \\
\hline 12 & 0.0247 & 2.90 & 7.64 & 51.7 & 28.1 \\
\hline 12 & 0.0237 & 2.88 & 7.64 & 32.2 & 29.2 \\
\hline 12 & 0.0242 & 2.89 & 7.64 & 42.3 & 28.6 \\
\hline 15 & 0.0583 & 2.73 & 7.54 & 22.3 & 11.9 \\
\hline 15 & 0.0679 & 2.67 & 7.48 & 29.6 & 10.2 \\
\hline 15 & 0.0661 & 2.70 & 7.41 & 25.7 & 10.5 \\
\hline 18 & 0.1114 & 2.92 & 7.88 & - & 6.22 \\
\hline 18 & 0.1053 & 2.97 & 7.78 & - & 6.58 \\
\hline 18 & 0.1082 & 2.95 & 7.81 & - & 6.41 \\
\hline 21 & 0.1739 & 3.30 & 7.69 & - & 3.98 \\
\hline 21 & 0.1869 & 3.38 & 7.74 & 4.9 & 3.70 \\
\hline 21 & 0.1860 & 3.34 & 7.72 & 4.3 & 3.73 \\
\hline 25 & 0.2879 & 3.28 & 8.04 & - & 2.41 \\
\hline 25 & 0.2841 & 3.49 & 8.00 & - & 2.44 \\
\hline 25 & 0.3039 & 3.39 & 8.02 & 2.3 & 2.28 \\
\hline
\end{tabular}

$\mu$ - specific growth rate, $\mathrm{N}_{0}-$ initial numbers of Lb. plantarum, $\mathrm{N}_{\max }-$ numbers in stationary phase, $\lambda-$ lag phase duration, $\mathrm{t}_{\mathrm{d}}$ - time to double, ${ }^{*}$ data from 2 parallel experiments, ${ }^{\circ}$ data from results of 2 parallel experiments.

Tab. 3. Growth characteristics of $L b$. plantarum at $30,34,35,37,38,40 \pm 0.5^{\circ} \mathrm{C}$.

\begin{tabular}{|c|c|c|c|c|c|}
\hline $\begin{array}{l}\text { Temperature } \\
{\left[{ }^{\circ} \mathrm{C}\right]}\end{array}$ & $\begin{array}{c}\mu \\
{\left[\mathbf{h}^{-1}\right]}\end{array}$ & $\begin{array}{c}\mathrm{N}_{0} \\
{\left[\log \mathrm{CFU} \cdot \mathrm{ml}^{-1}\right]}\end{array}$ & $\begin{array}{c}\mathbf{N}_{\max } \\
{\left[\log \mathbf{C F U} \cdot \mathbf{m l}^{-1}\right]}\end{array}$ & $\begin{array}{c}\lambda \\
{[\mathbf{h}]}\end{array}$ & $\begin{array}{c}\mathbf{t}_{\mathbf{d}} \\
{[\mathbf{h}]}\end{array}$ \\
\hline 30 & $0.4653^{*}$ & 3.00 & 7.71 & 3.7 & 1.49 \\
\hline 30 & $0.4669^{*}$ & 2.99 & 7.70 & 4.0 & 1.48 \\
\hline 30 & $0.4658^{\circ}$ & 3.00 & 7.70 & 3.8 & 1.49 \\
\hline 34 & 0.4602 & 3.07 & 7.38 & - & 1.51 \\
\hline 34 & 0.4922 & 3.04 & 7.43 & 3.3 & 1.41 \\
\hline 34 & 0.4899 & 3.06 & 7.41 & 3.7 & 1.41 \\
\hline 35 & 0.5485 & 2.98 & 7.34 & 3.5 & 1.26 \\
\hline 35 & 0.5434 & 3.04 & 7.46 & 3.9 & 1.28 \\
\hline 35 & 0.5461 & 3.01 & 7.36 & 3.7 & 1.27 \\
\hline 37 & 0.7441 & 3.02 & 7.65 & 2.1 & 0.93 \\
\hline 37 & 0.7443 & 2.96 & 7.62 & 2.0 & 0.90 \\
\hline 37 & 0.7683 & 2.99 & 7.64 & 2.1 & 0.90 \\
\hline 38 & 0.4249 & 3.11 & 7.08 & - & 1.63 \\
\hline 38 & 0.4282 & 3.08 & 7.28 & - & 1.62 \\
\hline 38 & 0.4568 & 3.09 & 7.18 & 1.50 & 1.52 \\
\hline 40 & 0.2133 & 3.18 & 6.83 & - & 3.24 \\
\hline 40 & 0.2316 & 3.08 & 6.72 & - & 2.99 \\
\hline 40 & 0.2224 & 3.13 & 6.78 & 8.0 & 3.11 \\
\hline
\end{tabular}

$\mu$ - specific growth rate, $\mathrm{N}_{0}$ - initial numbers of Lb. plantarum, $\mathrm{N}_{\max }-$ numbers in stationary phase, $\lambda$ - lag phase duration, $\mathrm{t}_{\mathrm{d}}$ - time to double, ${ }^{*}$ data from 2 parallel experiments, ${ }^{\circ}$ data from results of 2 parallel experiments. 
In a study of Medved'ová et al., (2016) Lactobacillus acidophilus NCFM in UHT milk reached about $73 \%$ higher specific growth rate $\left(0.827 \mathrm{~h}^{-1}\right)$ in comparison with our results at $40^{\circ} \mathrm{C}$.

\section{Conclusion}

Since the growth of microorganisms is strain dependent, it is necessary to know the growth dynamics of specific strains in dependence on environmental factors. Thus, the growth responses of the potentially probiotic Lactobacillus plantarum in UHT milk as affected by the incubation temperature were studied. Lb. plantarum showed good growth properties in the temperature range from 8 to $40{ }^{\circ} \mathrm{C}$. Cardinal temperatures using CTMI model $\left(T_{o p t}=34.7{ }^{\circ} \mathrm{C}\right.$, $T_{\min }=7.8{ }^{\circ} \mathrm{C}, T_{\max }=41.1{ }^{\circ} \mathrm{C}$ ) were evaluated with $\mu_{\text {opt }}=0.522 \mathrm{~h}^{-1}$. Due to the $\mathrm{pH}$ stability during its growth at evaluated incubation temperatures, could be added into pasteurized milk. In this case, pasteurized milk could be a carrier of potentially probiotic microorganism, because any significant $\mathrm{pH}$ changes were not recorded at all temperatures. For such a purpose it is important, that growth dynamics of used isolate in the applications is known.

\section{Acknowledgement}

This work was supported by STU Grant scheme for Support of Young Researchers no. 1617/16 and by the Slovak Research and Development Agency under the contract No. APVV-15-0006.

\section{References}

Arasu MV, AlDhabi NA, Ilavenil S, Choi KC, Srigopalram S (2015) Saudi Journal of Biological Sciences 23: $6-10$.
Baranyi J, Roberts TA (1994) Journal of Food Microbiology 23: 277-294.

Barrangou R, Lathinen SJ, Ibrahim F (2011) In: Lathinen S, Ouwehand AC, Salminen S, Von Wright A, Lactic acid bacteria, $4^{\text {th }}$ edition: 77-93.

JyotiBD, Suresh AK, Venkatesh KV (2004) Microbiological Research 159: 35-42.

Kleerebezem M, Boekhorst J, Kranenburg R, Molenaar D, Kuipers OP, Leer R (2003) Proceedings of the National Academy of Sciences of the United States of America, 100: 1990-1995.

Liptáková D, Koreňová J, Hornická M, Valík L' (2016) Lekársky obzor 65: 227-231.

Liptáková D, Valík L, Lauková A, Strompfová V (2007) Czech Journal of Food Sciences 25: 272-282.

Medved’ová A, Mančušková T, Valík L' (2016) Acta Alimentaria 45: 104-111.

Pelikánová D, Liptáková D, Valík L' (2011) Potravinárstvo 5: 187-191.

Rosso L, Lobry J, Flanders J (1993) Journal of Theoretical Biology 162: 447-463.

Salmerón I, Thomas K, Pandiella SS (2014) LWT - Food Science and Technology 55: 240-247.

Smetanková J, Hladíková Z, Valach F, Zimanová M, Kohajdová Z, Greif G, Greifová M (2012) Acta Chimica Slovaca 5: 204-210.

STN ISO 15214 (2002) Microbiology of food and animal feeding stuff: Horizontal method for enumeration of mesophilic lactic acid bacteria. Colony count technique.

Tannock GW (2004) Applied and Environmental Microbiology 70: 3189-3194.

Valík L, Medvedová A, Liptáková D (2008) Journal of Food and Nutrition Research 47: 60-67.

Valík L, Medvedová A, Bajúsová B, Liptáková D (2008) Journal of Food and Nutrition Research 47: 18-22.

Vaughan EE, Heilig HG, Ben-Amor K, de Vos WM (2005) FEMS Microbiology Reviews 29: 477-490.

Vries MC, Vaughan EE, Kleerebezem M, Vos WM (2006) International Dairy Journal 16: 1018-1028. 